\title{
PRAKTIK PENULISAN FEATURE DALAM MEMBANGUN LITERASI PADA ANAK-ANAK DI RPTRA MALINJO JAKARTA SELATAN
}

\author{
Dwi Kartikawati \\ Program Studi Ilmu Komunikasi FISIP Universitas Nasional Jakarta \\ Jl. Sawo Manila Pasar Minggu Jakarta Selatan \\ Penulis Korespodensi : dookartika@yahoo.com
}

\begin{abstract}
Abstrak
Ketrampilan menulis jurnalistik perlu dikenalkan kepada anak-anak sekolah, supaya dapat mengembangkan kreatifitas mereka. Bentuk tulisan jurnalistik yang dimaksud adalah feature. Dengan feature kita menginformasikan segala sesuatu, baik itu fakta, data, maupun peristiwa, termasuk pendapat dan pandangan tentang berbagai macam hal dengan tujuan memberikan pemahaman atau edukasi terhadap berbagai hal yang terjadi di sekitar kita. dan dapat membangun literasi.. Kegiatan praktik penulisan ini ditujukan kepada Anak-anak di Ruang Publik Terpadu Ramah Anak (RPTRA) Malinjo Pejaten Jakarta Selatan. Hasil dari kegiatan pengabdian masyarakat mengenai praktik penulisan ini menunjukan antusiasme tinggi karena anak anak langsung mengaplikasikan tulisan mereka melalui internet. Dengan kegiatan ini anak-anak diharapkan mampu menjadi agen agen perubahan untuk hal-hal yang positif di masa depan, dengan mengembangkan kreatifitas dalam menulis sehingga kemampuan literasi mereka meningkat.
\end{abstract}

Kata kunci: Praktik, Penulisan, Feature, Literasi

\section{Pendahuluan}

Perkembangan era teknologi informasi melalui internet berkembang pesat. Penggunaan gawai atau gadget sudah sangat biasa digunakn oleh semua kalangan masyarakat, salahsatunya anakanak remaja. Semestinya perkembangan tersebut harus diarahkan dan dimanfaatkan ke arah yang positif. Anak-anak ini sangat familier dengan gadget mereka. Mulai dari pemanfaatan sarana pertemanan, membaca informasi online, menonton kontenkonten di media sosial dan lain-lain. Jika kita tidak memiliki kemampuan melakukan filterisasi maka dikhawatirkan kita juga turut menyosialisasikan informasi yang tidak benar tersebut atau informasi sesat. Anak anak ini merupakan khalayak media yang cenderung pasif sehingga seringkali terpapar konten-konten media yang negatif yang tidak diharapkan. Untuk itu anak-anak perlu di berikan pengenalan secara aktif untuk dapat memanfaatkan ide-ide mereka dalam bentuk tulisan sehingga dapat melatih daya pikir dan kreatifitas mereka. Untuk itu anak anak perlu dikenalkan dengan ketrampilan menulis.

Keterampilan menulis dapat diajarkan melalui lembaga formal seperti sekolah atau pun lembaga non formal (Hidayah, 2019). Ketrampilan menulis yang diberikan adalah menulis dalam bentuk berita ringan yang disebut "feature", sebagai upaya pengenalan literasi media. Ini merupakan salah satu ketrampilan jurnalistik. Feature adalah sebuah tulisan jurnalistik juga, namun tidak selalu harus mengikuti rumus klasik $5 \mathrm{~W}+1$. Feature adalah berita ringan namun menarik.(M.A. Morissan, 2008)

Feature merupakan sebuah "karangan khas" yang menuturkan fakta, peristiwa, atau proses disertai penjelasan riwayat terjadinya, duduk perkaranya, proses pembentukannya, dan cara kerjanya. Dalam hal ini jenis-jenis feature di bagi menjadi dua yaitu (Juwito., 2008): (1) feature berita yaitu yang lebih banyak mengandung unsur berita, yang berkaitan dengan peristiwa yang sifatnya actual. Ini merupakan pengembaangan . (2) feature artikel yang lebih cenderung ke arah tulisan yang merupakan suatu pemikiran, mengenai ilmu pengetahuan dan lain-lain yang dikemas informatif yang dikemas ringan dan menghibur.

Feature digunakan untuk mengangkat nuansa atau warna kehidupan, hal yang sering tidak mungkin dilakukan lewat berita langsung. Persoalan aktual tidak menjadi masalah bagi feature. Itulah sebabnya feature tergolong berita 
yang ditulis penuh warna. Selain tidak terkait oleh waktu, berita khas juga membutuhkan kreatifitas penulisnya. Penulis harus rajin mencari sesuatu yang khas, kadang-kadang peristiwa biasa yang jarang terungkap dapat menjadi menarik. Tulisan mengenai suatu keadaan atau kejadian, seseorang, suatu hal, suatu pemikiran, tentang ilmu pengetahuan, dan lain-lain yang dikemukakan sebagai laporan (informasi) yang dikemas secara ringan dan menghibur. Menulis merupakan kegiatan manusia membuat dan mengolah simbol maupun lambang grafik menjadi sesuatu yang bermakna dan dapat dipahami oleh manusia lainnya.

Kemampuan menulis feature ini dapat mengembangkan daya literasi anak. Literasi didefinisikan sebagai kemampuan membaca dan menulis, atau bisa disebut melek aksara(Christianti, 2015). Dalam konteks sekarang, literasi memiliki arti yang sangat luas. Literasi dapat berarti melek teknologi, politik, berpikiran kritis, dan peka terhadap lingkungan sekitar. Literasi kontemporer sebagai kemampuan seseorang dalam menggunakan informasi tertulis atau cetak untuk mengembangkan pengetahuan, sehingga mendatangkan manfaat bagi masyarakat(Wartomo, 2017)

Ketrampilan menulis ini khususnya dalam rangka menginformasikan segala sesuatu, baik itu fakta, data, maupun peristiwa, termasuk pendapat dan pandangan tentang berbagai macam hal dengan tujuan memberikan pemahaman atau edukasi terhadap berbagai hal yang terjadi di sekitar kita. Dengan pengetahuan baru mengenai feature ini diharapkan anak anak akan dapat membangun literasi

Secara teoritis, ketrampilan menulis ini dipengaruhi oleh berbagai faktor antara lain: intensitas dalam kegiatan membaca, tingkat imaginasi yang dimiliki, kemampuan menulis berdasarkan pengalaman dan metode dan media yang digunakan (Baiq Desi Milandari \& Waluyan, 2018). Dengan demikian dengan kegiatan praktek penulisan feature ini, maka para perserta akan memiliki pengalaman dan juga pengetahuan dengan metode dan cara belajar langsung dengan praktek menuis langsung di media blog dan lain-lain.

Kegiatan ini dilakukan di RPTRA Malinjo Pejaten Jakarta Selatan. RPTRA atau Ruang Publik Terpadu Ramah Anak di wilayah Kelurahan Pejaten Barat merupakan konsep ruang publik berupa ruang terbuka hijau atau taman yang dilengkapi dengan berbagai permainan menarik, pengawasan CCTV, dan ruangan-ruangan yang melayani kepentingan komuniti yang ada. RPTRA dibangun berada di tengah pemukiman warga, terutama lapisan bawah dan padat penduduk, sehingga manfaatnya bisa dirasakan oleh warga sekitar khususnya anak-anak karena bagaimanapun mereka telah mengenal teknologi dan juga harus mampu menjadi agenagen perubahan untuk hal-hal yang positif di masa depan dengan salah satunya memilih kreatifitas dalam menulis feature. Kegiatan ini merupakan bagian dari kegiatan masyarakat Univerasitas Nasional Jakarta yang dilaksanakan dalam situasi di tengah pandemi penyakit Covid 19 yang masih sangat berbahaya. Untuk itu supaya mengantisipasi hal-hal yang tidak diinginkan apalagi situasi Jakarta masih dalam rangka pembatasan sosial berskala besar maka kegiatan ini secara daring dengan memberikan contoh langsung dan metode dalam mengaplikasikannya dengan melalui media Zoom dan WhatsApp Grup.

Kegiatan praktek penulisan feature ini ditujukan untuk anak-anak di RPTRA Malinjo Pejaten Jakarta Selatan. Kondisi Anak anak di wilayah RPTRA Malinjo Jakarta Selatan banyak yang menggunakan gadget dan belum banyak memiliki ketrampilan menulis. Di samping itu Anak-anak di wilayah RPTRA Malinjo Jakarta Selatan sangat perlu diberikan kreatifitas melalui kegiatan menulis dalam upaya membangun literasi mereka.

Dengan kegiatan ini diharapkan anak-anak RPTRA malinjo memiliki tambahan pengetahuan secara teoritis yakni dapat menulis feature, sedangkan secara praktis dapat memahami teknik menulis feature melalui internet yaitu melalui blog, dan lain-lai. Anak anak berlatih mengaktualisasikan diri, meningkatkan keterampilan jurnalistik.

\section{Bahan dan Metode}

Kegiatan praktik penulisan dalam membangun kemampuan literasi dengan sasaran adalah Anak anak di RPTRA Malinjo yang rata- rata usia SMP (Sekolah Menengah Pertama). Kegiatan Pengabdian Masyarakat ini dilaksanakan dengan melakukan secara daring dengan melalui media Zoom meeting dan WhatsApp Group mengingat situasi Jakarta masih dalam Pandemi Covid 19 dan juga media Whatshapp adalah media yang rata-rata dimiliki oleh anak-anak RPTRA dan juga supaya lebih fleksibel mengingat kesibukan anak-anak 
dalam melakukan sekolah formal mereka secara daring juga. Kegiatan di awali meeting online tim pengabdi untuk mempersiapkan seluruh rencana kegiatan Pengabdian Masyarakat yang dilaksanakan. Kegiatan ini dilaksanakan total 2 minggu dari mulai 19 Desember - 4 Januari 2021 2020 karena Anak-anak membutuhkan waktu untuk bisa praktek menulis di media internet seperti blog yang dimiliki masing-masing anak-anak. Peserta kegiatan berjumlah 15 anak anak didampingi 1 pengurus RPTRA serta 2 (dua) tim pengabdi dari Program Studi Ilmu Komunikasi FISIP Universitas Nasional Jakarta. Target peserta tercapai hampir $80 \%$. Yang akhirnya meng-upload tulisannya di di blog mereka. Angka tersebut menunjukkan bahwa kegiatan Pengabdian Masyarakat dilihat dari jumlah peserta yang mengikuti dapat dikatakan cukup berhasil. Ketercapaian tujuan pendampingan secara umum sudah baik, namun mesti bisa membagi antara waktu sekolah mereka secara daring dengan kegiatan PKM ini. Namun dilihat dari hasil latihan para peserta yang antusias telah berhasil, maka dapat disimpulkan bahwa tujuan kegiatan ini dapat tercapai. Ketercapaian target materi pada kegiatan Pengabdian Masyarakat ini cukup baik. Secara keseluruhan kegiatan ini dapat memberikan manfaat

\section{Hasil dan Pembahasan}

Kegiatan ini dilaksanakan dengan tujuan untuk membuat anak-anak memahami secara cerdas dalam mempraktekkan penulisan feature di internet supaya memperolah manfaat positif antara lain menambah wawasan dan keingintahuan yang tinggi terhadap berbagai macam informasi di sekitar kita. Pada kegiatan penulisan ini dibagi menjadi 4 kegiatan yaitu (1). Tahapan persiapan, (2) tahapan pelaksanaan. (3) Tahapan follow-up hasil tulisan melalui praktek, dan (4) tahapan evaluasi.

Pada tahapan persiapan dilakukan persiapan teknis yang meliputi persiapan menyediakan media Zoom dan pembuatan grup WhatsApp, kemudian berkerjasama dengan Kepala RPTRA dalam mengorganisir anak anak RPTRA untuk bergabung secara daring dan persiapan materi teoritis penulisan berita secara umum kemudian mengenai feature. Pada tahapan persiapan ini, dilakukan perkenalan awal melalui media grup whatsapp.
Pada tahapan pelaksanaan, adalah tahapan pemberian materi melalui zoom yang diikuti dengan tanya jawab dan penjelasan tahapan-tahapan penulisan. Untuk membuat suasana bersemangat maka anak anak terlebih dahulu menyapa dengan bahasa mereka yang ramah dengan panggilan ke tim pengabdi disebut 'kakak'. . Baru setelah itu disajikan materi melalui zoom meeting mengenai seluk beluk berita. Feature adalah bagian dari jenis berita juga.

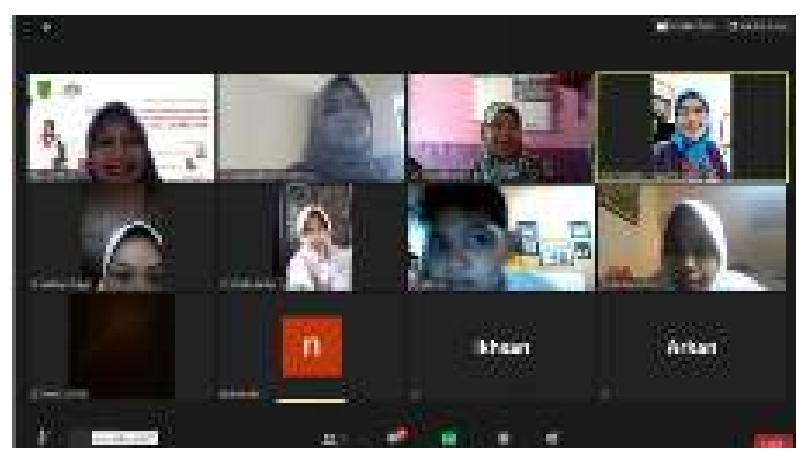

Gambar 1. Kegiatan pelaksanaan melalui media zoom

Pemberian materi diawali dengan penjelasan mengenai karakteristik berita dan feature, komponen berita dan feature, pengumpulan bahan penulisan, teknik dan prosedur penulisan berita dan feature. Pada praktek teknis penulisan feature secara detil termasuk bagaimana dalam menulis di blog dan lain-lain.

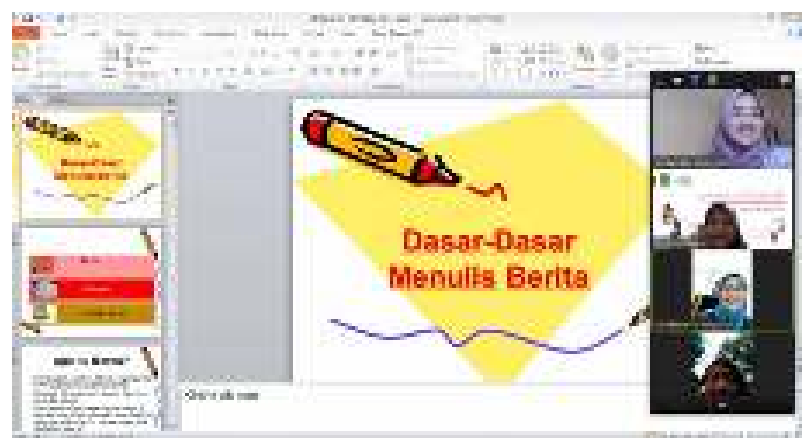

Gambar 2. Materi PPT

Pada tahap follow-up hasil dilakukan setelah para peserta berhasil meng-upload tulisannya di blog mereka. Semua peserta berhasil membuat blog tetapi hanya 2 orang yang tidak melakukan penulisan. Ketercapaian tujuan pelatihan secara umum sudah baik, namun ada Kendala terutama di follow-up hasil karena anak anak yang menjadi 
peserta ini harus membagi antara waktu sekolah mereka secara daring dengan kegiatan Pengabdian Masyarakat ini. Namun dilihat dari hasil latihan para peserta yang antusias telah berhasil, maka dapat disimpulkan bahwa tujuan kegiatan ini dapat tercapai. Ketercapaian target materi pada kegiatan kegiatan Pengabdian Masyarakat ini cukup baik. Semua peserta antusias mengikuti kegiatan ini yang dibawakan oleh tim pengabdi walaupun ketika pengumpulan anak anak dalam satu grup WhatshApp memerlukan waktu. Pelaksanaan kegiatan pengabdian ini masih sangat terbatas. Diharapkan ke depan nantinya bisa dilakukan kegiatan serupa yang sangat bermanfaat. Adapun hasil-hasil tulisan mereka dapat digambarkan di bawah ini:

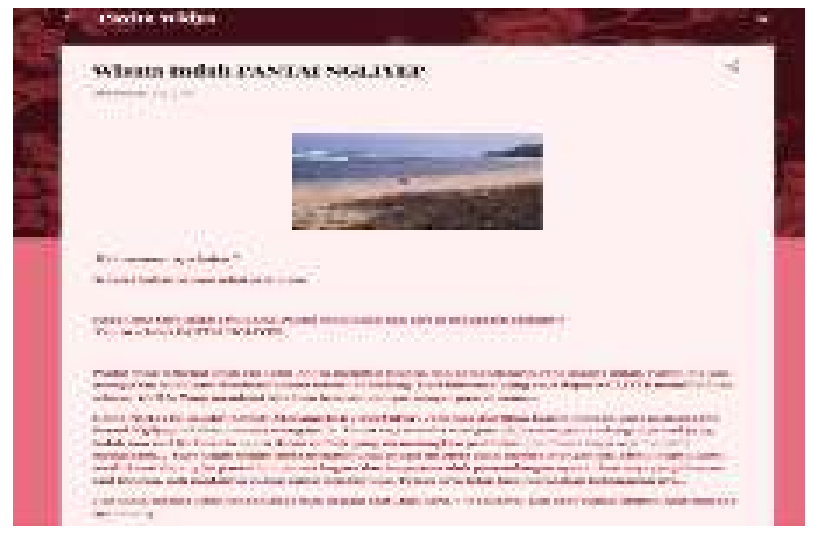

Gambar 3. Hasil tulisan feature yang dimuat di blog atas nama Pavita

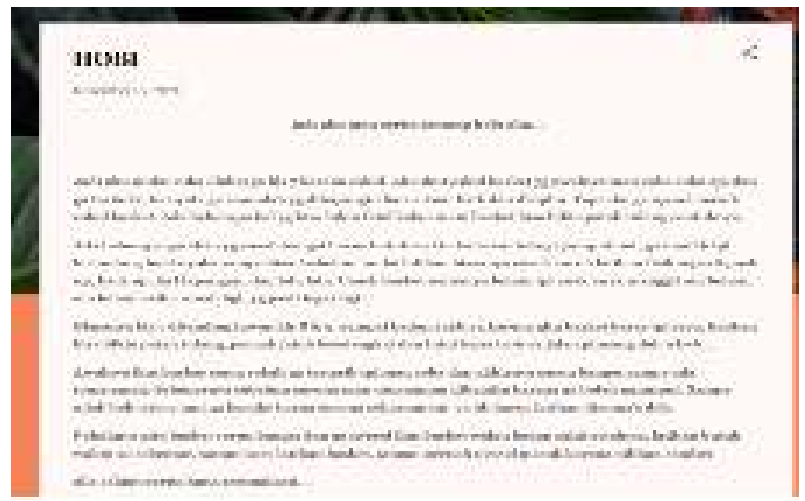

Gambar 4. Hasil tulisan feature yang dimuat di blog atas nama Hana

Pada tahapan evaluasi, terdapat berbagai kesulitan antara lain, pada proses pencarian ide, kemudian hambatan lain adalah pada hambatan waktu yang dirasa masih kurang untuk mengalokasikan khusus bagi anak anak RPTRA.
Untuk mengobarkan semangat dan apresiasi maka terpilih 10 peserta terbaik dalam pelatihan ini. Evaluasi bagi tim pengabdi adalah dari tulisan yang mereka buat, menjadi bahan pertimbangan, bahwa kegiatan menulis feature perlu dilakukan secara berkelanjutan, untuk dapat terus mengasah bakat peserta dalam menulis

Dengan hasil pelatihan yang cukup baik, maka tim pengabdi dari Universitas Nasional selalu berupaya memberikan semangat pada anak anak RPTRA ini untuk selalu meluangkan waktu menulis, karena dengan menulis berarti memiliki manfaat antara lain: mendokumentasikan gagasangagasan atau pemikiran-pemikiran, kemudian mendokumentasikannya atau melaporkan peristiwa yang terjadi dan yang terakhir mengkomunikasikan gagasan kita tentang peristiwa kepada pembaca.

\section{Kesimpulan}

Dari kegiatan pengabdian berupa pelatihan penulisan feature berjalan dengan baik, sehingga para peserta memahami mengenai seluk beluk mengenai berita dalam bentuk feature. Para peserta anak anak RPTRA juga dapat mempraktekkan secara langsung menulis berita dalam bentuk feature tersebut di media internet atau blog mereka. Kegiatan pengabdian berjalan dengan baik dan diharapkan hal ini akan terus berkelanjutan untuk mengasah minat menulis bagi anak anak RPTRA.

\section{Ucapan Terima Kasih}

Terima kasih disampaikan kepada Ketua LPPM UNAS yang telah mendanai kegiatan ini. Terima kasih disampaikan kepada Ibu Tati selaku Ketua RPTRA Malinjo Pejaten Jakarta Selatan yang telah memberikan kesempatan dan support pada tim pengabdi untuk mengajak anak anak RPTRA ikut serta dalam kegiatan pelatihan ini.

\section{Daftar Pustaka}

Baiq Desi Milandari, \& Waluyan, R. M. (2018). Menggunakan Metode Show Not Tell Pada Siswa Kelas V Mi Nahdlatul Mujahidin Nw Jempong, Ampenan. Jurnal Ulul Albab LPPM UMMAT, 22(2), 64-69. http://journal.ummat.ac.id/index.php/JUA/article/v iew/588/496

Christianti, M. (2015). Membaca dan Menulis Permulaan Untuk Anak Usia Dini. In Jurnal Pendidikan Anak (Vol. 2, Issue https://doi.org/10.21831/jpa.v2i2.3042

Hidayah, W. (2019). Peningkatkan Keterampilan 
Menulis Permulaan melalui Buku Harian Bergambar Siswa Kelas II B SD Timbulharjo Sewon Bantul. DIDAKTIKA: Jurnal Pendidikan Sekolah Dasar, 1(2), 59-68. https://doi.org/10.21831/didaktika.v1i2.28089

Juwito. (2008). Menulis Berita dan Feature 's. Unesa University Press.

M.A. Morissan. (2008). Managemen Media Penyiaran. Jakarta: Kencana Prenada Media Grup.

Wartomo. (2017). Membangun Budaya Literasi Sebagai Upaya Optimalisasi Perkembangan Bahasa Anak Usia Dini. Universitas Terbuka. http://repository.upy.ac.id/1815/2/24.

Wartomo\%2C M.Pd..pdf 